\title{
Necrològica
}

\section{Jean-François Lyotard}

Carlota Solé

Jean-François Lyotard (Versalles, 1924-París, 1998), filòsof i pensador social, va morir el 20 d'abril passat. Fundador del C ol-legi Internacional de Filosofia, fou professor a les U niversitats de la Sorbona, $\mathrm{N}$ anterre i V incennes, com també a la universitat nord-americana d'Emory. D e la seva extensa obra destaquen: A partir de M arx y Freud (1973), Economía libidinal (1974), La condición postmoderna (1979), La postmodernidad (expli cada a los niños) (1982), Le différent (1983). Les seves útimes obres foren C hambre sourde (1998) i C onfession d'Agustin, pendents de publicació en el moment del seu traspàs. Influït per M erleau-Ponty, començà els seus treballs de reflexió filosòfica en el camp de la fenomenologia. Coneixedor i crític del pensament marxista, fou actiu en el grup Socialisme o Barbarie, de tanta influència en el pensament d'esquerra antitotalitarista, i indirectament, en el moviment revolucionari del M aig del 68 a França i altres països europeus. Juntament amb altres pensadors francesos contemporanis, com ara: Cornelius Castoriadis, Jacques D errida, $\mathrm{M}$ ichel Foucault, Baudrillard, D eleuze, Lipovetsky i Virilio, dóna embranzida al pensament filosòfic i social a la França de les darreres dècades.

Participà en el polèmic debat a finals de la dècada dels setanta sobre la superació i fi de l'era de la modernitat i l'entrada a la postmodernitat. La discussió teòrica amb Jürgen $\mathrm{H}$ abermas, reflectida en el Ilibre de Lyotard: La condición post-moderna (Informe sobre el saber) (1979), el dugué a intentar destruir la creença subjacent a bona part de l'obra del pensador alemany sobre la humanitat com a subjecte col-lectiu (universal) que persegueix la seva pròpia emancipació a través de la regularització dels distints moviments o païssos, permesos en tots els jocs de llenguatge (en el sentit de W ittgenstein); i que la legitimació de qual sevol enunciat radica en la seva contribució a aquesta emancipació.

Per a Lyotard, el consensus en les ciències modernes no és una finalitat sinó un estadi en la discussió científica. La finalitat del saber o ciència moderna és la paralogia. La ciència postmoderna s'ocupa de qüestions que no són separables dels límits del control extrem, de conflictes que es caracteritzen per la seva informació incompleta, «fracta», per catàstrofes, per paradoxes pragmàtiques. En el seu teoritzar segueix una evolució discontínua, catastròfica, no rectifica- 
ble i paradòxica (Lyotard, J .-F., 1984 (1979): 13-19). Al fons, està argumentant sobre si mantenir o no la contraposició entre «consensus vertader» $i$ «fals consensus», o bé, entre «validesa» i «poder» per explicar el que és «vertader» 0 «vàlid». $\mathrm{H}$ abermas es resisteix a substituir la idea de «el millor argument» com oposat a l'«argument que convenç un determinat públic, en un determinat moment». Caure en aquest tipus de crítica traïria els «elements de raó en la modernitat cultural que estan continguts... en els ideals burgesos», és a dir: «la dinàmica teòrica interna que impulsa constantment les ciències i l'autoreflexió de les ciències, més enllà de la creació d'un coneixement merament explotable 0 aplicable tecnològicament». (J. H abermas, 1982: 18)1.

Lyotard analitza la transformació que ha experimentat el saber en les socie tats avançades: el saber es basa en la informatització. Es troba en contrast amb el saber com a progrés, que ha donat lloc als discursos típics i propis de la «modernitat» del Segle de les Llums. Es refereix als metarelats següents: I'iluminista (el saber és legítim ja que contribueix a l'emancipació de la societat civil), l'idealista (el saber, desinteressat, no té fins determinats), i el marxista (el saber afavoriria l'emancipació del proletariat, distingint-se objectivament de ciència i ideologia). El saber, avui, esdevé en canvi mercaderia mediàtica, un vehicle tècnic d'intercanvi, de comunicació, de traducció, d'informació.

En l'època postmoderna no existeix per a Lyotard connexió possible entre els ordres de l'estètica, la moral i la política, com en l'època de la modernitat de la II·lustració. $\mathrm{H}$ i ha, al contrari, incomunicació entre aquestes tres diferents «famílies de frases», ja que existeix una heterogeneïtat de jocs de llenguatge, seguint la famosa expressió de W ittgentstein. Així, la crisi del saber científic no prové d'una proliferació fortuitta de les ciències que fóra l'efecte del progrés de les tècniques i de l'expansió del capitalisme, sinó que procedeix de l'erosió interna del principi de legitimitat del saber. Actualment, el criteri de legitimitat és, per a Lyotard, performativitat. L'increment de poder i la seva autolegitimació es basa ara en la producció, memorització, accessibilitat i operacionalitat; I'objectiu final és l'optimització o augment de l'output (informacions o modificacions de les rebudes) i disminució de l'input (energia invertida o gastada per obtenir-les).

Aquestes reflexions despertaren i desperten polèmica, tot i que Lyotard s'avança en vint anys a posar èmfasi en les comunicacions i la informació com a generadores de coneixement i com a eix central en les noves formes de producció (de serveis) que envaeixen progressivament els àmbits privat, personal i àdhuc íntim dels individus membres de les societats avançades. La influència del pensament filosòfic de Lyotard en la discussió sobre la modernitat i el procés de modernització deixa de nou palès el paper cabdal de la filosofia com a branca del saber que talla transversalment diverses de les discussions teòriques d'altres disciplines socials, com ara la sociologia.

1. H ABERM AS, J. (1982). «T he Entnoinement of $M$ yth and Enlightenment. Rereading D ialectic of Enlightenment». N ew German Critique, 24. 